\title{
Critical assessment of the elemental composition of Corning archeological reference glasses by LA-ICP-MS
}

\author{
B. Wagner • A. Nowak $\cdot$ E. Bulska $\cdot$ K. Hametner • \\ D. Günther
}

Received: 26 September 2011 /Revised: 18 November 2011 / Accepted: 20 November 2011 /Published online: 8 December 2011

(C) The Author(s) 2011. This article is published with open access at Springerlink.com

\begin{abstract}
Corning archeological reference glasses A, B, C, and $\mathrm{D}$ have been made to simulate different historic technologies of glass production and are used as standards in historic glass investigations. In this work, nanoseconds $(193,266 \mathrm{~nm})$ and femtosecond $(800 \mathrm{~nm})$ laser ablation were used to study the elemental composition of Corning glasses using laser ablation inductively coupled plasma mass spectrometry. The determined concentrations of 26 oxides $\left(\mathrm{Li}_{2} \mathrm{O}, \mathrm{B}_{2} \mathrm{O}_{3}, \mathrm{Na}_{2} \mathrm{O}, \mathrm{MgO}, \mathrm{Al}_{2} \mathrm{O}_{3}, \mathrm{SiO}_{2}, \mathrm{P}_{2} \mathrm{O}_{5}\right.$, $\mathrm{K} 2 \mathrm{O}, \mathrm{CaO}, \mathrm{TiO}_{2}, \mathrm{~V}_{2} \mathrm{O}_{5}, \mathrm{Cr}_{2} \mathrm{O}_{3}, \mathrm{MnO}, \mathrm{Fe}_{2} \mathrm{O}_{3}, \mathrm{CoO}, \mathrm{NiO}$, $\mathrm{CuO}, \mathrm{ZnO}, \mathrm{Rb}_{2} \mathrm{O}, \mathrm{SrO}, \mathrm{ZrO}_{2}, \mathrm{SnO}_{2}, \mathrm{Sb}_{2} \mathrm{O}_{5}, \mathrm{BaO}, \mathrm{PbO}$, $\mathrm{Bi}_{2} \mathrm{O}_{3}$ ) are compared with values reported in the literature. Results show variable discrepancies between the data, with the largest differences found for $\mathrm{Cr}_{2} \mathrm{O}_{3}$ in Corning $\mathrm{A} ; \mathrm{Li}_{2} \mathrm{O}$, $\mathrm{B}_{2} \mathrm{O}_{3}$, and $\mathrm{Cr}_{2} \mathrm{O}_{3}$ in Corning $\mathrm{B}$; and $\mathrm{MnO}, \mathrm{Sb}_{2} \mathrm{O}_{5}, \mathrm{Cr}_{2} \mathrm{O}_{3}$, and $\mathrm{Bi}_{2} \mathrm{O}_{3}$ in Corning $\mathrm{C}$. The best agreement between the measured and literature values was found for Corning $\mathrm{D}$. However, even for this reference, glass re-evaluation of the data was necessary and new values for $\mathrm{PbO}, \mathrm{BaO}$, and $\mathrm{Bi}_{2} \mathrm{O}_{3}$ are proposed.
\end{abstract}

Keywords Glass $\cdot$ Standards $\cdot$ Archeometry $\cdot$ LA-ICP-MS

B. Wagner $(\bowtie) \cdot$ A. Nowak $\cdot$ E. Bulska

Faculty of Chemistry, University of Warsaw,

Pasteura 1,

02093 Warsaw, Poland

e-mail: barbog@chem.uw.edu.pl

K. Hametner $\cdot$ D. Günther

Laboratory of Inorganic Chemistry,

Department of Chemistry and Applied Biosciences, ETH Zurich,

Wolfgang-Pauli-Str. 10,

8093 Zurich, Switzerland

\section{Introduction}

The knowledge about the elemental composition of historic glasses is crucial for establishing their age, provenance, or the technology used for their production [1-6]. The required chemical information can be obtained from instrumental techniques, which offer variable sensitivity as well as limits of detection [7-10] exploiting various reference materials to support method validation and evaluation of the measurement uncertainty. The limited collection of available solid reference materials limits the quality assurance and quality control when analyzing solids. Archeometrical analyses are additionally complicated by the uniqueness of the analyzed historic objects, and measurements need to be performed non-destructively or pseudo non-destructively using microsampling [7, 11-21].

For historic glass analysis, laser ablation inductively coupled plasma mass spectrometry (LA-ICP-MS) is a good choice, because it offers direct micro-sampling by focused laser beam and fast multielemental determination with low detection limits [7, 22-25]. This method has been widely and successfully used for elemental analysis of historic glasses [5, 11, 21, 26-29], although the lack of suitable matrix-matched solid standards is still recognized as an important limitation and prevents insights into the accuracy achievable with this technique.

Glass standards in analysis of historic objects

Taking into account the widely varying composition of historic glass, the selection of appropriate matrix-matched solid reference materials is difficult $[2,11]$. The most popular glass reference materials are those which are available from NIST (National Institute of Standards and Technology) in form of wafers. These have been widely used as calibration materials 
for LA-ICP-MS analysis of historic glass [21, 27-30]. The silicate matrix (Si-Na-Ca-Al) of NIST SRM 610 to 617 is doped with the well-known concentrations of 61 elements. However, the composition of historic glasses usually differs considerably from the major element composition of these reference materials. To meet these analytical needs, Corning archeological reference glasses: A, B, C, and D have been produced by the Corning Museum of Glass (USA). These materials reflect the different technologies of historic glass production. Glasses A and B mimic the composition typical for Egyptian, Mesopotamian, Roman, Byzantine, and Islamic glasses; $\mathrm{C}$ is similar to glasses from East Asia, and D reflects glasses, which have been produced from the seventeenth to the nineteenth centuries $[2,31,32]$.

High purity synthetic oxides and carbonates, $\mathrm{NaCl}$, $\mathrm{NH}_{4} \mathrm{H}_{2} \mathrm{PO}_{3}$, alumina hydrate, natural $\mathrm{ZrSiO}_{4}$, and $\mathrm{SiO}_{2}$ have been used as precursor materials to produce the Corning glasses [31]. Trace elements have been mixed in two groups (Ti, Sn, B, Ba, Sr, Li, Rb and V, K, Ag, Zr, Ni, Zn, Bi) and ball-milled prior to incorporation. The precursor mixtures were melted, stirred, and quenched in deionized water, then crushed, and re-melted again. The rehomogenized melt was poured into 1-cm-thick sheets. Two groups of elements can be distinguished in the elemental composition of Corning glasses [31,32]. The first group includes the elements which oxides have been determined by a number of techniques, i.e., gravimetry, polarography, flame photometry, atomic absorption, X-ray fluorescence, or neutron activation $\left(\mathrm{SiO}_{2}, \mathrm{Al}_{2} \mathrm{O}_{3}, \mathrm{Fe}_{2} \mathrm{O}_{3}, \mathrm{MgO}, \mathrm{CaO}, \mathrm{Na}_{2} \mathrm{O}, \mathrm{K}_{2} \mathrm{O}, \mathrm{MnO}\right.$, $\mathrm{P}_{2} \mathrm{O}_{5}, \mathrm{TiO}_{2}, \mathrm{Sb}_{2} \mathrm{O}_{5}, \mathrm{CuO}, \mathrm{PbO}, \mathrm{CoO}, \mathrm{BaO}, \mathrm{SnO}_{2}, \mathrm{SrO}$, and $\mathrm{ZnO}$ ). The second group includes the oxides for which nominal compositions were calculated from mass fractions of the precursor constituents added to the batch $\left(\mathrm{B}_{2} \mathrm{O}_{3}\right.$, $\mathrm{Li}_{2} \mathrm{O}, \mathrm{Rb}_{2} \mathrm{O}, \mathrm{V}_{2} \mathrm{O}_{5}, \mathrm{Cr}_{2} \mathrm{O}_{3}, \mathrm{NiO}, \mathrm{ZrO}_{2}, \mathrm{Bi}_{2} \mathrm{O}_{3}$ ). It can be assumed that the results obtained by several laboratories should be more reliable then indicative information about the contents of the oxides calculated for the second group, although Corning archeological reference glasses are not characterized by a metrologically valid procedure. These glasses have been mainly used for estimation of the precision and accuracy of measurements in several investigations of historic glass objects [5, 11, 17, 27, 29, 30, 33-40], because large amounts of elemental concentration data have been published for them $[11,27,31,32,37-40]$. The contents of the literature values of the oxides used in this study are from Vicenzi [32] who referred to Brill [2] (Table 1).

Brief revision of the literature

Brill $[2,31]$ coordinated the first interlaboratory investigations of elemental compositions of the Corning archeological reference glasses and published recommended and nominal values. Tentative recommended values were given in 1971 [31], with emphasis that these preliminary values would need further evaluation. The final compositions of Corning glasses were published by Brill [2] in 1999, and they were then used as the recommended ones [32]. These values have been used for calibration in quantitative analyses of historic glasses and to check the accuracy of the methods used, although the principles of quality control were not always sufficiently documented [33, 40-43]. The deficiency of information about the obtained precision and accuracy can be noticed in some reports [33, 40, 43] as well as the lack of identifying the Corning glass used [42]. In some cases, even when the accuracy and precision were given and discussed in the text, the detailed results of these control measurements were omitted [17, 34, 35].

Corning C and D were used by Kuisma-Kursula [36, 37] to determine the accuracy of the measurements. Bronk and Freestone [38] validated the usefulness of the scanning electron microscopy/energy-dispersive X-ray analysis in analyzing glass objects with the use of Corning $\mathrm{A}$ and B. They described the influence of the procedure used for the preparation of the Corning glasses to the final results and reported problems with quantification of some oxides $\left(\mathrm{Sb}_{2} \mathrm{O}_{5}, \mathrm{PbO}\right.$ in Corning $\left.\mathrm{B}\right)$. Other authors [39] reported inconvenience of quantification of $\mathrm{SnO}_{2}$, in Corning C. The most comprehensive and multitechnique (electron probe micro-analysis (EPMA), LA-ICP-MS, secondary ion mass spectrometry) investigations of Corning archeological reference glasses were described by Vicenzi et al. [32]. This study reports the determination of minor and trace elements and their distribution in the Corning glasses. The agreement of the presented EPMA results with recommended values is highly variable, while the general agreement between LA-ICP-MS and previously published data is within $5 \%$ to $20 \%$. EPMA measurements validated heterogeneous distribution of some elements $(\mathrm{SrO}, \mathrm{ZnO}$ in all glasses, and $\mathrm{BaO}, \mathrm{SnO}_{2}$ in Corning $\mathrm{B}$ ), while LA-ICP-MS indicated relatively high degree of the compositional uniformity of all the Corning glasses which were examined using $193 \mathrm{~nm}$ laser with beam diameter of $23 \mu \mathrm{m}$. The details of the LA-ICP-MS results have been discussed for Corning A, $\mathrm{B}$, and $\mathrm{D}$. A value of the $\mathrm{MnO}$ content in Corning $\mathrm{C}$ has been reported here for the first time [32].

LA-ICP-MS has also been applied by Shortland et al. [30] for the determination of trace elements in glass objects using Corning A as a quality control for the accuracy of the measurements. The authors concluded that the agreement of their results with the values recommended by Vicenzi et al. [32] was rather poor. It is important to note that the most significant discrepancies have been observed for $\mathrm{Cr}_{2} \mathrm{O}_{3}$ (161\%), $\mathrm{PbO}, \mathrm{SnO}_{2}$, and $\mathrm{SrO}$ (about 30\%). The quantitative results of $\mathrm{MnO}$ in Corning $\mathrm{C}$ with a mean content of 0.001 wt.\% obtained in our laboratory [11] or published by Dussubieux $[26,27]$ varied strongly from the value given 
Table 1 Major, minor and trace element oxide compositions of Corning archeological reference glasses A, B, C, D [32], and NIST 610

\begin{tabular}{|c|c|c|c|c|c|}
\hline & Corning A, wt.\% & Corning B, wt.\% & Corning C, wt.\% & Corning D, wt. $\%$ & NIST SRM 610, wt. $\%$ \\
\hline $\mathrm{SiO}_{2}$ & 66.56 & 61.55 & 34.87 & 55.24 & 70.20 \\
\hline $\mathrm{Al}_{2} \mathrm{O}_{3}$ & 1.00 & 4.36 & 0.87 & 5.30 & 1.880 \\
\hline $\mathrm{Fe}_{2} \mathrm{O}_{3}$ & 1.09 & 0.34 & 0.34 & 0.52 & 0.058 \\
\hline $\mathrm{MgO}$ & 2.66 & 1.03 & 2.76 & 3.94 & 0.077 \\
\hline $\mathrm{CaO}$ & 5.03 & 8.56 & 5.07 & 14.8 & 11.50 \\
\hline $\mathrm{Na}_{2} \mathrm{O}$ & 14.3 & 17.0 & 1.07 & 1.20 & 12.80 \\
\hline $\mathrm{K}_{2} \mathrm{O}$ & 2.87 & 1.00 & 2.84 & 11.3 & 0.059 \\
\hline $\mathrm{MnO}$ & 1.00 & 0.25 & 0.82 & 0.55 & 0.056 \\
\hline $\mathrm{P}_{2} \mathrm{O}_{5}$ & 0.13 & 0.82 & 0.14 & 3.93 & 0.078 \\
\hline $\mathrm{TiO}_{2}$ & 0.79 & 0.089 & 0.79 & 0.38 & 0.072 \\
\hline $\mathrm{Sb}_{2} \mathrm{O}_{5}$ & 1.75 & 0.46 & 0.03 & 0.97 & 0.039 \\
\hline $\mathrm{CuO}$ & 1.17 & 2.66 & 1.13 & 0.38 & 0.054 \\
\hline $\mathrm{PbO}$ & 0.12 & 0.61 & 36.7 & 0.48 & 0.045 \\
\hline $\mathrm{CoO}$ & 0.17 & 0.046 & 0.18 & 0.023 & 0.052 \\
\hline $\mathrm{BaO}$ & 0.56 & 0.12 & 11.4 & 0.51 & 0.047 \\
\hline $\mathrm{SnO}_{2}$ & 0.19 & 0.04 & 0.19 & 0.10 & 0.050 \\
\hline $\mathrm{SrO}$ & 0.10 & 0.019 & 0.29 & 0.057 & 0.059 \\
\hline $\mathrm{ZnO}$ & 0.044 & 0.19 & 0.052 & 0.10 & 0.056 \\
\hline $\mathrm{B}_{2} \mathrm{O}_{3}$ & 0.20 & 0.02 & 0.20 & 0.10 & 0.115 \\
\hline $\mathrm{Li}_{2} \mathrm{O}$ & 0.01 & 0.001 & 0.01 & 0.005 & 0.104 \\
\hline $\mathrm{Rb}_{2} \mathrm{O}$ & 0.01 & 0.001 & 0.01 & 0.005 & 0.047 \\
\hline $\mathrm{V}_{2} \mathrm{O}_{5}$ & 0.006 & 0.03 & 0.006 & 0.015 & 0.079 \\
\hline $\mathrm{Cr}_{2} \mathrm{O}_{3}$ & 0.001 & 0.005 & 0.001 & 0.003 & 0.057 \\
\hline $\mathrm{NiO}$ & 0.02 & 0.10 & 0.02 & 0.05 & 0.057 \\
\hline $\mathrm{ZrO}_{2}$ & 0.005 & 0.025 & 0.005 & 0.013 & 0.059 \\
\hline $\mathrm{Bi}_{2} \mathrm{O}_{3}$ & 0.001 & 0.005 & 0.001 & 0.003 & 0.040 \\
\hline
\end{tabular}

by Vicenzi [32]. Dussubieux [27] reported for few elements, not only $\mathrm{Mn}$ in Corning $\mathrm{C}$, that the concentrations provided by Brill [2] might not be accurate.

Aim of the work

The evaluation of the published data revealed various inconsistencies between the recommended and determined values of several constituents of Corning archeological reference glasses, which are of interest to both archeologists and art historians. Corning archeological reference glasses are widely used as calibration or validation materials for the analysis of historic glass. Therefore, the reliability and usefulness of the available data requires a careful reexamination.

The aim of this work was focused on a detailed investigation of the composition of Corning archeological reference glasses A, B, C, and D using LA-ICP-MS. Therefore, various nanosecond $(\lambda=193,266 \mathrm{~nm})$ and femtosecond $(\lambda=$ $800 \mathrm{~nm}$ ) laser wavelengths were used for sampling. The quantification scheme is based on NIST 610 , and the results of each individual sampling using commonly applied wavelengths for archeological studies are summarized and discussed in comparison to literature data.

\section{Experimental}

Samples and standard

Three different types of archeological reference glasses, which were fabricated to mimic historic glass recipes, were investigated: Corning glass $\mathrm{A}$ and Corning glass $\mathrm{B}$ are Na-rich/Ca-bearing silicates; Corning Glass $\mathrm{C}$ is rich in $\mathrm{Pb}$ and $\mathrm{Ba}$ while Corning Glass $\mathrm{D}$ is $\mathrm{K}$ - and Ca-rich silicate [31, 32] (Table 1).

Standard glass NIST SRM 610 was used as the external standard. The similarity of the bulk composition of NIST 610 to the composition of the Corning glasses [32] was considered to be close to the matrix composition of the Corning glass matrix. Therefore, reduced influence of element fractionation effects on the calculated results was 
(A)

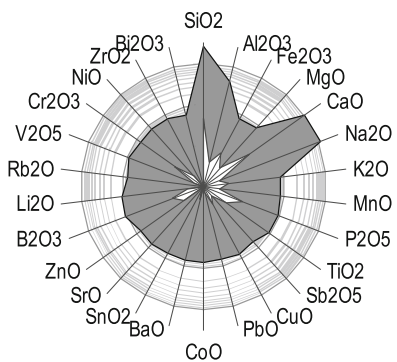

(B)

(C)

(D)

(E)

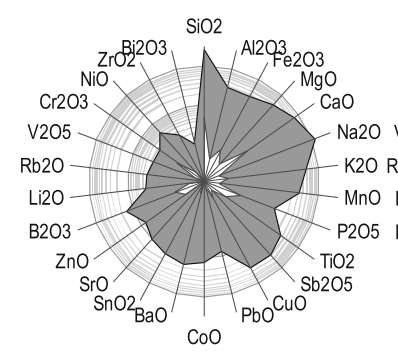

$\mathrm{R}^{2}=0.9864$

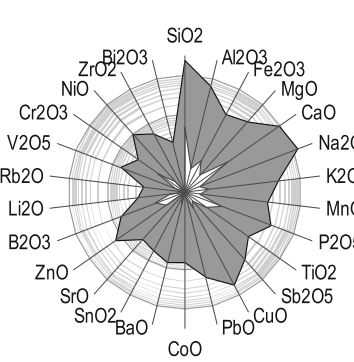

$\mathrm{R}^{2}=0.9880$

Fig. 1 The relationship between the oxides concentration in calibration: NIST $610(A)$ and unknown samples: Corning A $(B)$; Corning B $(C)$, Corning $\mathrm{C}(D)$, and Corning $\mathrm{D}(E)$. White patterns in the middle

assumed. The comparison of the calibration materials and samples with the correlation coefficient indicating the relationship between the oxides concentration in calibration and unknown samples is given in Fig. 1. The matrix-matching is acceptable for three of the four investigated glasses $\left(R^{2}=\right.$ 0.9864 for Corning A; $R^{2}=0.9880$ for Corning $\mathrm{B}$, and $R^{2}=$ 0.9150 for Corning D), and it is most significantly different for the Corning C $\left(R^{2}=0.4034\right)$, when compared with the other glasses.

Instrumentation

LA-ICP-MS was used in this study with the involvement of three different laser systems (Table 2):

1. The laser ablation system LSX-200 ${ }^{+}$(CETAC, USA) combining a stable, environmentally sealed $266-\mathrm{nm}$ UV laser (Nd-YAG, solid-state, Q-switched) was coupled to inductively coupled plasma mass spectrometer ELAN 9000 (Perkin Elmer SCIEX, Canada). All experiments were performed using $\mathrm{Ar}$ as the carrier gas.

2. The 193-nm ArF-Excimer laser (GeoLas Compex, MicroLas, Goettingen, Germany) was coupled to ELAN 6100 (Perkin Elmer, Norwalk, CT, USA).

3. The Ti/sapphire femtosecond laser system (Legend, Coherent Inc., Santa Clara, CA, USA) was coupled to Elan DRC II (Perkin Elmer SCIEX, Thornhill, Canada). All ablations

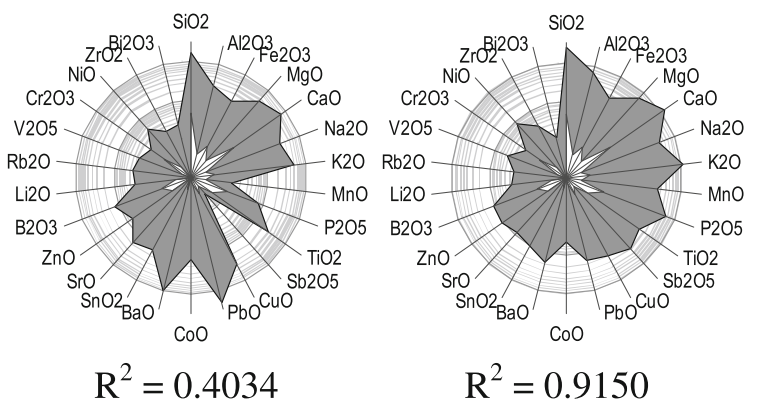

part of the chart visualizes limits of detection for the respective elements. The values of $R^{2}$ given below the charts show correlation coefficient of the NIST vs Cornings

Table 2 Instrumental settings, operating conditions, and data acquisition parameters

\begin{tabular}{|c|c|c|c|}
\hline \multicolumn{4}{|c|}{ Laser system parameters and settings } \\
\hline \multicolumn{4}{|c|}{ Laser ablation characteristics and settings } \\
\hline Wavelength, nm & 193 & 266 & 800 \\
\hline Pulse duration & $15 \mathrm{~ns}$ & $5 \mathrm{~ns}$ & $150 \mathrm{fs}$ \\
\hline Energy density, $\mathrm{Jcm}^{-2}$ & 23.9 & 15.9 & 15.1 \\
\hline Beam diameter, $\mu \mathrm{m}$ & 40 & 100 & 130 \\
\hline Repetition rate, $\mathrm{Hz}$ & 10 & 10 & 5 \\
\hline \multicolumn{4}{|c|}{ ICP MS characteristics and settings } \\
\hline RF Power & 1370 & 1050 & 1350 \\
\hline Neb. gas flow rate & 0.85 & 0.98 & 1.0 \\
\hline Plasma gas flow rate & 16.7 & 16.0 & 17.0 \\
\hline Carrier gas & $\mathrm{He}$ & $\mathrm{Ar}$ & $\mathrm{He}$ \\
\hline \multicolumn{4}{|c|}{ ICP MS data acquisition parameters } \\
\hline Scanning mode & \multicolumn{3}{|c|}{ Peak hopping } \\
\hline Dwell time, ms & \multicolumn{3}{|c|}{10} \\
\hline Pre-integration time, $\mathrm{s}$ & \multicolumn{3}{|c|}{30} \\
\hline Integration time, $\mathrm{s}$ & \multicolumn{3}{|c|}{60} \\
\hline Isotopes monitored & \multicolumn{3}{|c|}{$\begin{array}{l}{ }^{7} \mathrm{Li},{ }^{11} \mathrm{~B},{ }^{23} \mathrm{Na},{ }^{25} \mathrm{Mg},{ }^{27} \mathrm{Al},{ }^{29} \mathrm{Si},{ }^{31} \mathrm{P},{ }^{39} \mathrm{~K}, \\
{ }^{42} \mathrm{Ca},{ }^{48} \mathrm{Ti},{ }^{49} \mathrm{Ti},{ }^{51} \mathrm{~V},{ }^{53} \mathrm{Cr},{ }^{55} \mathrm{Mn},{ }^{57} \mathrm{Fe}, \\
{ }^{59} \mathrm{Co},{ }^{60} \mathrm{Ni},{ }^{61} \mathrm{Ni},{ }^{65} \mathrm{Cu},{ }^{66} \mathrm{Zn},{ }^{85} \mathrm{Rb},{ }^{88} \mathrm{Sr}, \\
{ }^{90} \mathrm{Zr},{ }^{118} \mathrm{Sn},{ }^{121} \mathrm{Sb},{ }^{135} \mathrm{Ba},{ }^{137} \mathrm{Ba},{ }^{208} \mathrm{~Pb}, \\
{ }^{209} \mathrm{Bi}\end{array}$} \\
\hline
\end{tabular}


which were carried out using the 193 and $800 \mathrm{~nm}$ lasers were performed using $\mathrm{He}$ as the sample carrier gas, which was mixed with Ar before entering the ICP.

For all measurements, the samples were placed inside the ablation cell with NIST SRM 610. The calibration material was measured twice at the beginning and twice at the end of each run to correct for instrumental drift using the algorithm proposed by Longerich et al. [44]. Seven replicate single point ablations at locations randomly selected on the glass surface were carried out on each sample. Transient signals were recorded and evaluated for subsequent elemental quantification. The LA-ICP-MS signals were backgroundcorrected and integrated using LAMTRACE program developed by Jackson [45]. Table 3 summarizes the average limits of detection for the different types of laser wavelengths used for sampling (for crater diameter, see operating conditions, Table 2).

The results for all samples were calculated using $\mathrm{SiO}_{2}$ as the internal standard, applying the data displayed in Table 1. Normalization was performed to the total content reported

Table 3 Calculated limits of detection (LOD) for the different types of laser wavelengths used for sampling

\begin{tabular}{|c|c|c|c|}
\hline wt.\% & $\mathrm{LOD}_{193}$ & $\mathrm{LOD}_{266}$ & $\mathrm{LOD}_{800}$ \\
\hline $\mathrm{SiO}_{2}$ & 0.02110 & 0.01640 & 0.00925 \\
\hline $\mathrm{Al}_{2} \mathrm{O}_{3}$ & 0.00018 & 0.00012 & 0.00004 \\
\hline $\mathrm{Fe}_{2} \mathrm{O}_{3}$ & 0.00068 & 0.00048 & 0.00019 \\
\hline $\mathrm{MgO}$ & 0.00015 & 0.00030 & 0.00010 \\
\hline $\mathrm{CaO}$ & 0.00553 & 0.02040 & 0.00134 \\
\hline $\mathrm{Na}_{2} \mathrm{O}$ & 0.00007 & 0.00003 & 0.00017 \\
\hline $\mathrm{K}_{2} \mathrm{O}$ & 0.00016 & 0.00006 & 0.00008 \\
\hline $\mathrm{MnO}$ & 0.00006 & 0.00001 & 0.00001 \\
\hline $\mathrm{P}_{2} \mathrm{O}_{5}$ & 0.00103 & 0.00089 & 0.00074 \\
\hline $\mathrm{TiO}_{2}$ & 0.00024 & 0.00028 & 0.00007 \\
\hline $\mathrm{Sb}_{2} \mathrm{O}_{5}$ & 0.00004 & 0.00004 & 0.00002 \\
\hline $\mathrm{CuO}$ & 0.00009 & 0.00003 & 0.00004 \\
\hline $\mathrm{PbO}$ & 0.00002 & 0.00002 & 0.00002 \\
\hline $\mathrm{CoO}$ & 0.00001 & 0.00001 & 0.00001 \\
\hline $\mathrm{BaO}$ & 0.00004 & 0.00002 & 0.00002 \\
\hline $\mathrm{SnO}_{2}$ & 0.00002 & 0.00003 & 0.00000 \\
\hline $\mathrm{SrO}$ & 0.00001 & 0.00001 & 0.00001 \\
\hline $\mathrm{ZnO}$ & 0.00015 & 0.00060 & 0.00004 \\
\hline $\mathrm{B}_{2} \mathrm{O}_{3}$ & 0.00042 & 0.00023 & 0.00034 \\
\hline $\mathrm{Li}_{2} \mathrm{O}$ & 0.00006 & 0.00002 & 0.00004 \\
\hline $\mathrm{Rb}_{2} \mathrm{O}$ & 0.00001 & 0.00001 & 0.00001 \\
\hline $\mathrm{V}_{2} \mathrm{O}_{5}$ & 0.00003 & 0.00002 & 0.00001 \\
\hline $\mathrm{Cr}_{2} \mathrm{O}_{3}$ & 0.00045 & 0.00015 & 0.00007 \\
\hline $\mathrm{NiO}$ & 0.00005 & 0.00070 & 0.00008 \\
\hline $\mathrm{ZrO}_{2}$ & 0.00001 & 0.00001 & 0.00001 \\
\hline $\mathrm{Bi}_{2} \mathrm{O}_{3}$ & 0.00001 & 0.00001 & 0.00001 \\
\hline
\end{tabular}

by Vicenzi [32] as 99.79 wt.\% for Corning A; 99.33 wt.\% for Corning B; $99.80 \mathrm{wt} . \%$ for Corning C; and $99.97 \mathrm{wt} . \%$ for Corning D. Therefore, although the initial contents of $\mathrm{SiO}_{2}$ as the internal standard were given according to the literature [34], the final contents differed from these recommended values after normalization.

\section{Results and discussion}

Analysis of corning archeological reference glasses by means of LA-ICP-MS

The results of Corning archeological reference glasses [31, 32] measured using various laser wavelengths and pulse width for sampling by LA-ICP-MS are given in Table 4. It was found that the results acquired with different laser wavelengths varied significantly and that the $193 \mathrm{~nm}$ ns or $800 \mathrm{~nm}$ fs lasers provided the comparable results, while the $266 \mathrm{~nm}$ ns laser showed most significant deviations.

\section{Homogeneity of Corning glasses}

The homogeneity of the Corning glasses has already been reported by Vicenzi et al. [32]. The majority of the concentrations of the elements reported in Table 4 were determined with relative standard deviations less than $5 \%$. The mean $\mathrm{Sb}_{2} \mathrm{O}_{5}$ in Corning $\mathrm{C}$ is the only exception, with the high relative standard deviations obtained for the all laser wavelengths used in this study (RSD $=19 \%$ for 193 ns-laser, $\mathrm{RSD}=12 \%$ for 266 ns-laser, and $\mathrm{RSD}=26 \%$ for 800 fslaser ablation). The mean $\mathrm{Sb}_{2} \mathrm{O}_{5}$ in Corning $\mathrm{C}$ was calculated consequently as equal to the $c=0.0001 \mathrm{wt} . \%$. irrespective of the laser wavelength. However, these results suggest an inhomogeneous distribution of $\mathrm{Sb}$ in Corning $\mathrm{C}$.

Comparison of the results obtained after ablation by means of $193 \mathrm{~ns}, 266 \mathrm{~ns}$, and 800 Fs lasers

The ratios of the measured to the literature [32] values for each oxide element of the Corning glasses are displayed in Fig. 2.

The deviations of the results acquired within this study to the recommended values caused variable shapes of radarcharts for the overall chemical composition of particular Corning glasses (Fig. 2). Analogous shapes of the charts for different laser wavelengths could be obtained if the interaction of these lasers with sample of identical composition was similar. However, it is known that both laser wavelength and pulse duration affect the degree of fractionation, therefore, some differences of the results were expected. Fractionation effects often are reduced by the use of shorter wavelengths (e.g., ns-193 nm) and shorter 
Table 4 Major, minor, and trace element oxide compositions of Corning archeological reference glasses A, B, C, and D

\begin{tabular}{|c|c|c|c|c|c|c|}
\hline wt. $\%$ & $193 \mathrm{~nm}$ & $266 \mathrm{~nm}$ & $800 \mathrm{~nm}$ & $193 \mathrm{~nm}$ & $266 \mathrm{~nm}$ & $800 \mathrm{~nm}$ \\
\hline & Corning A & & & Corning B & & \\
\hline $\mathrm{SiO}_{2}$ & $67.82(0.4)$ & NA & $68.90(0.2)$ & $62.02(0.3)$ & $57.72(3.1)$ & $63.94(0.3)$ \\
\hline $\mathrm{Al}_{2} \mathrm{O}_{3}$ & $0.820(2.4)$ & NA & $1.08(3.2)$ & $4.63(1.3)$ & $7.76(1.6)$ & $4.02(1.4)$ \\
\hline $\mathrm{Fe}_{2} \mathrm{O}_{3}$ & $0.979(1.3)$ & NA & $0.979(0.1)$ & $0.311(1.5)$ & $0.268(0.7)$ & $0.307(1.2)$ \\
\hline $\mathrm{MgO}$ & $2.50(1.6)$ & NA & $2.11(0.4)$ & $0.988(0.7)$ & $1.18(2.0)$ & $0.789(1.7)$ \\
\hline $\mathrm{CaO}$ & 4.94 (1.9) & NA & $5.36(3.3)$ & $8.75(1.4)$ & $13.7(0.6)$ & $9.12(1.2)$ \\
\hline $\mathrm{Na}_{2} \mathrm{O}$ & $13.4(0.7)$ & NA & $13.6(1.2)$ & $16.5(0.5)$ & $13.9(2.0)$ & $16.0(0.6)$ \\
\hline $\mathrm{K}_{2} \mathrm{O}$ & $3.46(1.1)$ & NA & $2.46(1.2)$ & $1.30(1.4)$ & $0.876(2.6)$ & $0.827(2.5)$ \\
\hline $\mathrm{MnO}$ & $1.13(1.3)$ & NA & $0.969(0.7)$ & $0.241(1.2)$ & $0.238(0.9)$ & $0.230(0.9)$ \\
\hline $\mathrm{P}_{2} \mathrm{O}_{5}$ & $0.085(0.8)$ & NA & $0.088(1.1)$ & $0.611(0.8)$ & $0.417(2.8)$ & $0.633(1.2)$ \\
\hline $\mathrm{TiO}_{2}$ & $0.739(2.2)$ & NA & $0.771(3.7)$ & 0.099 (1.9) & $0.145(1.1)$ & $0.101(0.9)$ \\
\hline $\mathrm{Sb}_{2} \mathrm{O}_{5}$ & $1.86(1.0)$ & NA & $1.44(1.4)$ & $0.418(1.8)$ & $0.289(1.1)$ & $0.401(0.8)$ \\
\hline $\mathrm{CuO}$ & $1.10(1.8)$ & NA & $1.19(0.5)$ & $2.82(1.7)$ & $2.23(4.4)$ & $2.57(0.6)$ \\
\hline $\mathrm{PbO}$ & $0.073(0.9)$ & NA & 0.059 (2.9) & $0.532(2.5)$ & $0.388(1.5)$ & $0.331(2.3)$ \\
\hline $\mathrm{CoO}$ & $0.170(1.3)$ & NA & $0.167(0.7)$ & $0.043(0.8)$ & $0.037(2.4)$ & $0.043(1.0)$ \\
\hline $\mathrm{BaO}$ & $0.46(2.2)$ & NA & 0.278 & $0.077(2.5)$ & $0.109(3.0)$ & $0.052(5.1)$ \\
\hline $\mathrm{SnO}_{2}$ & $0.171(1.1)$ & NA & $0.173(0.7)$ & $0.024(0.9)$ & $0.022(4.2)$ & $0.024(0.4)$ \\
\hline $\mathrm{SrO}$ & $0.106(1.8)$ & NA & $0.110(2.4)$ & 0.017 (1.9) & $0.028(2.3)$ & $0.019(1.0)$ \\
\hline $\mathrm{ZnO}$ & 0.048 (1.6) & NA & $0.051(2.4)$ & $0.211(1.7)$ & $0.177(1.4)$ & $0.216(0.9)$ \\
\hline $\mathrm{B}_{2} \mathrm{O}_{3}$ & $0.274(5.3)$ & NA & $0.214(1.1)$ & $0.036(6.4)$ & $0.021(0.9)$ & $0.032(3.4)$ \\
\hline $\mathrm{Li}_{2} \mathrm{O}$ & $0.011(2.9)$ & NA & $0.011(1.9)$ & 0.003 (4.6) & $0.002(4.3)$ & $0.003(0.9)$ \\
\hline $\mathrm{Rb}_{2} \mathrm{O}$ & 0.009 (1.4) & NA & $0.010(0.4)$ & $0.001(2.3)$ & $0.001(6.4)$ & 0.001 \\
\hline $\mathrm{V}_{2} \mathrm{O}_{5}$ & $0.007(2.3)$ & NA & 0.007 (1.2) & $0.034(1.2)$ & 0.029 & $0.033(0.6)$ \\
\hline $\mathrm{Cr}_{2} \mathrm{O}_{3}$ & 0.003 (4.9) & NA & $0.003(8.0)$ & 0.010 & $0.008(2.1)$ & $0.009(2.4)$ \\
\hline $\mathrm{NiO}$ & $0.023(2.2)$ & NA & $0.028(11)$ & $0.094(1.1)$ & $0.079(3.1)$ & $0.091(1.5)$ \\
\hline $\mathrm{ZrO}_{2}$ & $0.005(2.7)$ & NA & $0.006(3.8)$ & $0.023(2.7)$ & 0.053 (1.6) & $0.025(1.9)$ \\
\hline \multirow[t]{2}{*}{$\mathrm{Bi}_{2} \mathrm{O}_{3}$} & $0.001(3.0)$ & NA & $0.001(5.7)$ & $0.004(2.4)$ & $0.004(0.7)$ & $0.004(0.8)$ \\
\hline & Corning C & & & Corning D & & \\
\hline $\mathrm{SiO}_{2}$ & $31.41(0.5)$ & $32.87(2.1)$ & $28.36(0.3)$ & $28.36(1.2)$ & $56.59(3.3)$ & $57.11(0.2)$ \\
\hline $\mathrm{Al}_{2} \mathrm{O}_{3}$ & $0.736(1.2)$ & $1.58(2.2)$ & $0.772(0.8)$ & $5.19(3.0)$ & $4.82(1.9)$ & $4.40(0.9)$ \\
\hline $\mathrm{Fe}_{2} \mathrm{O}_{3}$ & $0.262(0.8)$ & $0.244(3.5)$ & $0.277(0.9)$ & $0.460(2.1)$ & $0.459(2.9)$ & $0.480(0.8)$ \\
\hline $\mathrm{MgO}$ & $2.50(0.7)$ & $3.00(1.4)$ & $2.02(1.1)$ & $3.87(1.3)$ & $4.43(0.6)$ & $3.86(0.9)$ \\
\hline $\mathrm{CaO}$ & $4.75(0.8)$ & $8.24(0.7)$ & $4.84(0.4)$ & $14.7(2.4)$ & $18.3(2.4)$ & $15.5(0.6)$ \\
\hline $\mathrm{Na}_{2} \mathrm{O}$ & $0.966(0.6)$ & 1.17 (1.4) & $0.848(1.3)$ & $1.30(1.4)$ & $1.31(2.1)$ & $1.31(1.0)$ \\
\hline $\mathrm{K}_{2} \mathrm{O}$ & $3.21(0.3)$ & $1.87(1.4)$ & $2.45(1.8)$ & $14.2(0.7)$ & $8.69(1.5)$ & $11.1(0.2)$ \\
\hline $\mathrm{MnO}$ & $0.001(3.1)$ & 0.001 (3.6) & $0.001(4.8)$ & $0.597(1.1)$ & $0.499(3.3)$ & $0.531(0.8)$ \\
\hline $\mathrm{P}_{2} \mathrm{O}_{5}$ & $0.068(1.8)$ & $0.054(3.9)$ & $0.062(0.4)$ & $3.05(0.9)$ & $2.26(4.4)$ & $3.08(0.8)$ \\
\hline $\mathrm{TiO}_{2}$ & $0.706(0.6)$ & 1.10 (1.6) & $0.753(0.4)$ & $0.356(2.7)$ & $0.413(2.9)$ & $0.371(0.6)$ \\
\hline $\mathrm{Sb}_{2} \mathrm{O}_{5}$ & $0.0001(19)$ & $0.0001(12)$ & $0.0001(26)$ & $0.961(1.9)$ & $0.572(3.4)$ & $0.780(0.3)$ \\
\hline $\mathrm{CuO}$ & $1.10(0.5)$ & $1.00(2.7)$ & $1.15(0.4)$ & $0.370(1.6)$ & $0.356(1.7)$ & $0.37(0.9)$ \\
\hline $\mathrm{PbO}$ & $39.8(0.5)$ & $34.2(2.7)$ & $47.8(0.4)$ & $0.241(1.4)$ & $0.213(2.2)$ & $0.222(0.7)$ \\
\hline $\mathrm{CoO}$ & $0.164(0.4)$ & $0.150(4.9)$ & $0.170(0.7)$ & $0.018(1.3)$ & $0.018(2.8)$ & $0.020(6.6)$ \\
\hline $\mathrm{BaO}$ & $13.3(0.6)$ & $13.4(2.1)$ & $9.47(2.2)$ & $0.291(1.8)$ & $0.374(3.2)$ & $0.285(3.6)$ \\
\hline $\mathrm{SnO}_{2}$ & $0.163(0.8)$ & $0.173(1.5)$ & $0.172(0.8)$ & $0.084(1.9)$ & $0.080(6.9)$ & $0.088(0.8)$ \\
\hline $\mathrm{SrO}$ & $0.333(0.5)$ & $0.439(4.1)$ & $0.308(1.5)$ & $0.055(2.6)$ & $0.070(5.1)$ & $0.059(0.3)$ \\
\hline $\mathrm{ZnO}$ & $0.042(1.1)$ & $0.050(3.3)$ & $0.046(0.5)$ & 0.102 (1.6) & $0.097(3.7)$ & $0.104(0.7)$ \\
\hline $\mathrm{B}_{2} \mathrm{O}_{3}$ & $0.187(1.3)$ & $0.154(2.3)$ & $0.167(1.0)$ & $0.105(3.0)$ & $0.083(1.3)$ & $0.107(0.7)$ \\
\hline $\mathrm{Li}_{2} \mathrm{O}$ & $0.009(2.4)$ & $0.008(3.2)$ & $0.008(0.8)$ & $0.006(1.3)$ & $0.006(3.4)$ & $0.006(0.9)$ \\
\hline $\mathrm{Rb}_{2} \mathrm{O}$ & $0.008(0.5)$ & $0.008(5.0)$ & $0.010(0.3)$ & $0.005(2.0)$ & $0.005(1.7)$ & 0.005 \\
\hline
\end{tabular}


Table 4 (continued)

\begin{tabular}{|c|c|c|c|c|c|c|}
\hline wt. $\%$ & $193 \mathrm{~nm}$ & $266 \mathrm{~nm}$ & $800 \mathrm{~nm}$ & $193 \mathrm{~nm}$ & $266 \mathrm{~nm}$ & $800 \mathrm{~nm}$ \\
\hline $\mathrm{V}_{2} \mathrm{O}_{5}$ & $0.006(0.9)$ & $0.006(2.2)$ & $0.007(0.6)$ & $0.017(1.1)$ & $0.017(2.3)$ & $0.018(0.6)$ \\
\hline $\mathrm{Cr}_{2} \mathrm{O}_{3}$ & $0.002(3.3)$ & $0.002(8.1)$ & $0.003(8.3)$ & $0.003(4.1)$ & $0.003(2.2)$ & $0.004(1.0)$ \\
\hline $\mathrm{NiO}$ & 0.018 (1.4) & $0.016(6.9)$ & $0.022(4.7)$ & 0.048 (1.4) & $0.048(3.3)$ & $0.053(10)$ \\
\hline $\mathrm{ZrO}_{2}$ & $0.004(1.4)$ & $0.012(6.3)$ & $0.006(0.4)$ & $0.011(4.9)$ & 0.014 (1.9) & $0.012(0.7)$ \\
\hline $\mathrm{Bi}_{2} \mathrm{O}_{3}$ & $0.004(1.1)$ & $0.005(4.2)$ & $0.007(1.0)$ & $0.001(3.7)$ & $0.001(2.9)$ & $0.001(1.8)$ \\
\hline
\end{tabular}

The average results expressed in weight percentage [wt.\%] obtained after ablation of the glasses with various laser wavelengths are given in the subsequent columns - 193, 226, or $800 \mathrm{~nm}$, respectively

RSD values are given in brackets (percent)

NA not analyzed

pulse widths (e.g., fs- $800 \mathrm{~nm}$ ) [46, 47], and the results obtained with these laser wavelengths for the most of elements were comparable.

The analyzed Corning glass results obtained using a $266 \mathrm{~nm}$ laser differed to some extent from the results obtained using ablation with 193- and 800-nm wavelength lasers. The most pronounced difference was observed for the soda-lime-silica glass (Fig. 2, Corning B) but can also be seen in the pattern for the high-lead-and-barium glass (Fig. 2, Corning C). The differences of the respective results for potash-lime-silica glass (Fig. 2, Corning D) are low. The highest differences in all samples were observed for $\mathrm{Al}_{2} \mathrm{O}_{3}, \mathrm{CaO}, \mathrm{ZrO}_{2}, \mathrm{Bi}_{2} \mathrm{O}_{3}, \mathrm{SrO}$, and $\mathrm{K}_{2} \mathrm{O}$ when ablating at $266 \mathrm{~nm}$ when compared with 193 or $800 \mathrm{~nm}$ lasers. Inconsistent results for $\mathrm{PbO}$ were obtained for the high-lead-andbarium glass (Corning $\mathrm{C}$ ).

Apart from the mentioned inconsistencies, some systematic variations from the recommended values for each Corning glass can be noticed, and these values will be discussed in more detail. Independent of the lasers used for ablation,
Fig. 2 The ratios of the measured to the recommended values calculated for the results obtained by means of LA-ICPMS for Corning B, C, and D after ablation by 193,800 , and $266 \mathrm{~nm}$ lasers
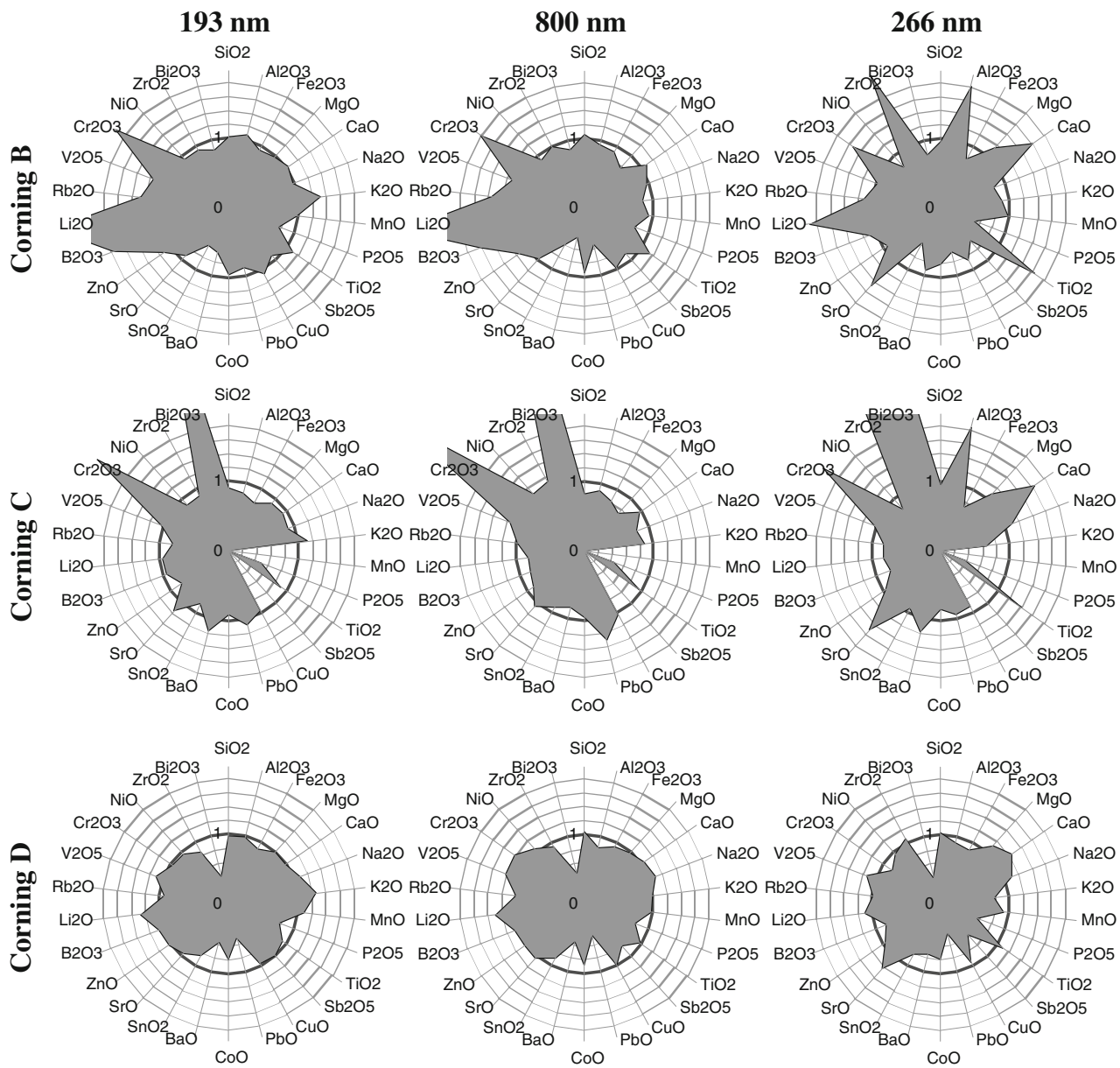
all data showed an underestimation of $\mathrm{SnO}_{2}$ and overestimation of $\mathrm{Li}_{2} \mathrm{O}$ and $\mathrm{Cr}_{2} \mathrm{O}_{3}$ in Corning $\mathrm{B}$ as well as underestimation of $\mathrm{MnO}$ and $\mathrm{Sb}_{2} \mathrm{O}_{2}$ and overestimation of $\mathrm{Cr}_{2} \mathrm{O}_{3}$ and $\mathrm{Bi}_{2} \mathrm{O}_{3}$ in Corning $\mathrm{C}$ with respect to the recommended values [32]. The data for Corning D are in good agreement with the data reported by Brill [31], which indicates and accurate characterization. However, $\mathrm{Bi}_{2} \mathrm{O}_{3}, \mathrm{PbO}$, and $\mathrm{BaO}$ differ significantly and indicate an overestimation in the literature.

The $266 \mathrm{~nm}$ shows the largest and non-coherent, with the other lasers (193 ns and 800 fs lasers), deviations from the expected values, therefore, the quantitative results obtained using this laser wavelength are excluded from the further comparisons. The use of $193-\mathrm{nm}$ laser wavelength creates smaller particles which are more effectively transported and ionized in the plasma and thus exhibit less elemental fractionation compared with $266 \mathrm{~nm}$ lasers [48]. Also, the use of femtosecond laser pulses $(800 \mathrm{~nm})$ has been reported to be beneficial for LA-ICP-MS measurements [49]. Therefore, the data acquired using these two types of lasers will be discussed in more detail.
Fig. 3 z-Score values for the LA-ICP-MS results of Corning glasses analyzed using 193 and $800 \mathrm{~nm}$ laser ablation

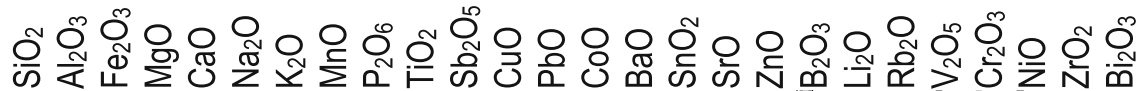

A)

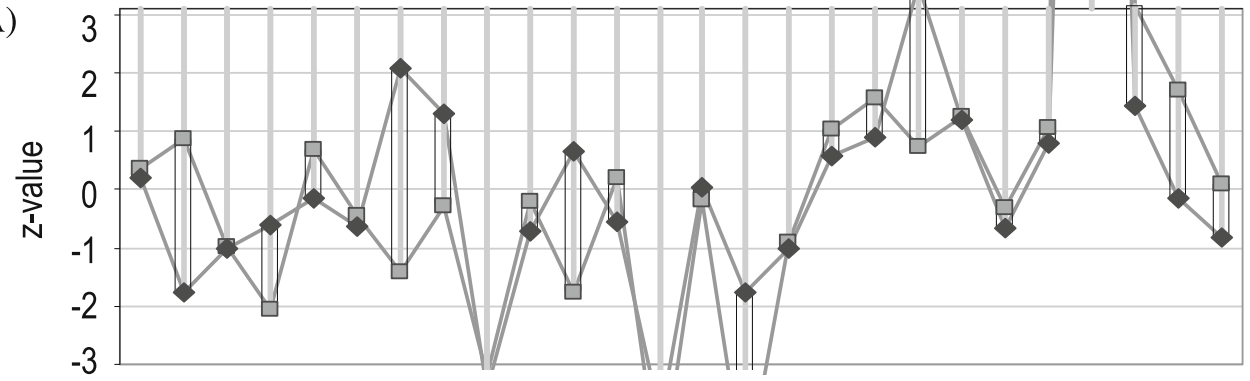

B)

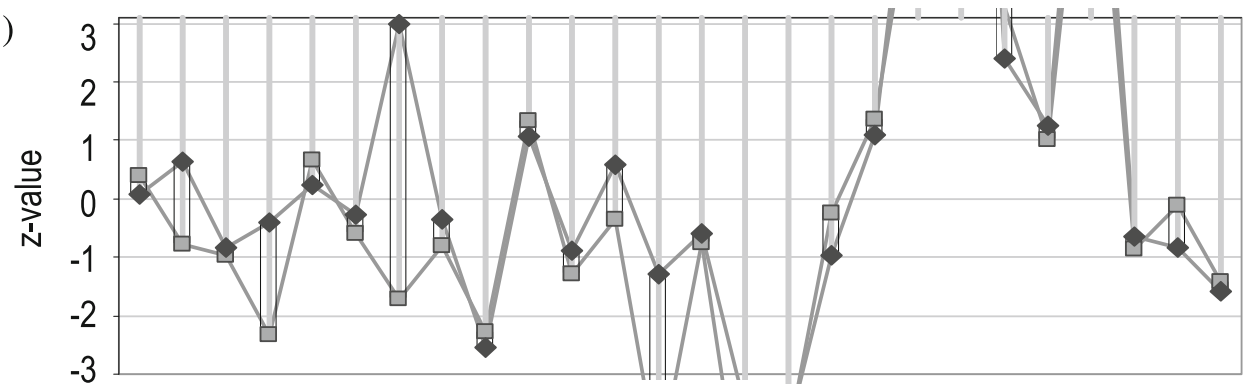

C)

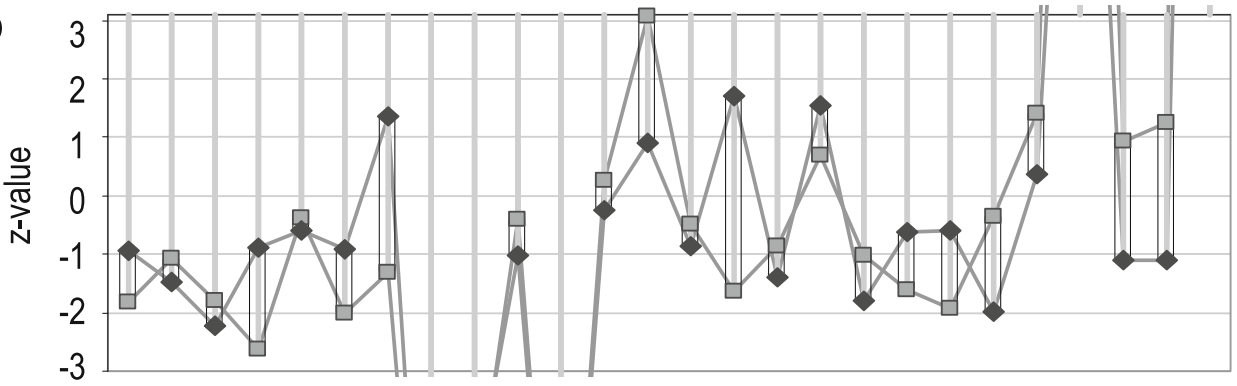

D)

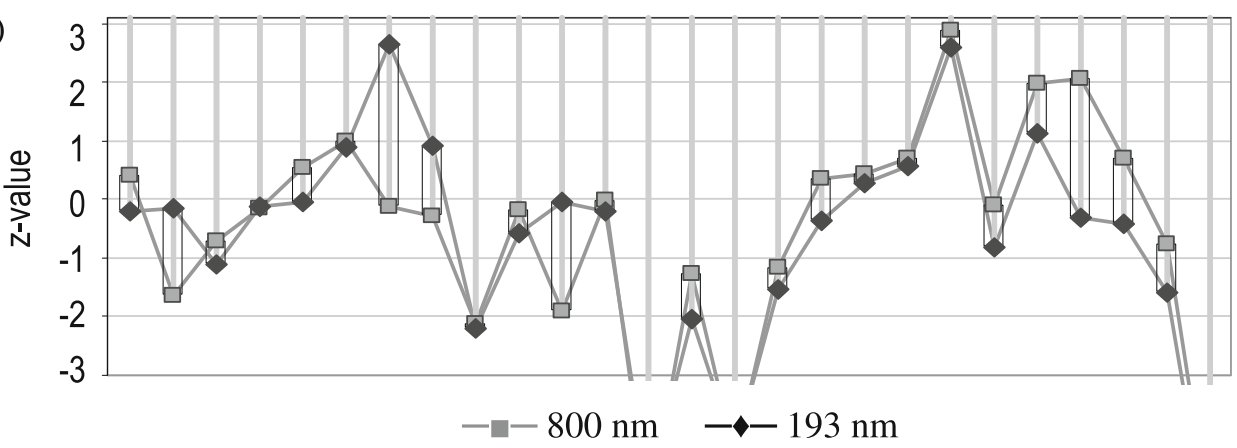


Recommended and determined values for 800 and $193 \mathrm{~nm}$ lasers

The recommended contents of the oxides were compared with data acquired using 800 and $193 \mathrm{~nm}$. Discrepancies between these values were evaluated using the $\mathrm{z}$-scores for each individual result. The target standard deviation was assigned as $10 \%$ of the recommended value for each element, because the information about the relative standard deviations could only be extracted from the report describing individual results of four repetitive inductively coupled plasma-optical emission spectrometry measurements of Corning glasses from Brill [2]. The calculated values of RSDs exceeded $10 \%$ for three oxides: $\mathrm{PbO}$ in Corning $\mathrm{A}$ ( $X_{\text {rec }}=0.120$ wt. $\%, \mathrm{SD}_{\mathrm{t}}=0.043$ wt. $\%, \mathrm{RSD}=35.5 \%$ ), $\mathrm{Al}_{2} \mathrm{O}_{3}$ in Corning $\mathrm{C}\left(X_{\mathrm{rec}}=0.870\right.$ wt. $\%, \mathrm{SD}_{\mathrm{t}}=0.115$ wt.\%., RSD= $13.2 \%)$, and $\mathrm{Sb}_{2} \mathrm{O}_{5}$ in Corning $\mathrm{C}\left(X_{\mathrm{rec}}=0.025\right.$ wt. $\%, \mathrm{SD}_{\mathrm{t}}=$ 0.006 wt.\%, RSD=23.1\%). The high RSD of the mean content was confirmed by our LA-ICP-MS study only for $\mathrm{Sb}_{2} \mathrm{O}_{5}$ in Corning $\mathrm{C}$. Therefore, the $\mathrm{SD}_{\mathrm{t}}$ applied was taken from Brill [2].

Generally, the z-scores are acceptable (within $\pm 2 ; 95 \%$ ) and unacceptable when the score is outside \pm 3 (greater than $99 \%$ ), and questionable with intermediated values. The calculated z-score values for the oxides in Corning glasses were used to indicate discrepancies between the measured and recommended data (Fig. 3). The values which were outside the calculated threshold for both wavelengths (193 and $800 \mathrm{~nm}$ ) indicated the need of a re-evaluation of the recommended concentrations in the Corning glass. Most of the results acquired in this study agree with the published and recommended values [2, 31, 32], but some discrepancies were found for different oxides in all Corning glasses (Fig. 3). The results of $\mathrm{P}_{2} \mathrm{O}_{5}, \mathrm{PbO}, \mathrm{BaO}$, and $\mathrm{Cr}_{2} \mathrm{O}_{3}$ were found unacceptable in Corning $\mathrm{A} ; \mathrm{BaO}, \mathrm{SnO}_{2}, \mathrm{~B}_{2} \mathrm{O}_{5}, \mathrm{Li}_{2} \mathrm{O}$, $\mathrm{Cr}_{2} \mathrm{O}_{3}$, and $\mathrm{BiO}_{3}$ in Corning $\mathrm{B} ; \mathrm{MnO}, \mathrm{P}_{2} \mathrm{O}_{5}, \mathrm{Sb}_{2} \mathrm{O}_{5}, \mathrm{Cr}_{2} \mathrm{O}_{3}$, and $\mathrm{Bi}_{2} \mathrm{O}_{3}$ in Corning $\mathrm{C}$; and $\mathrm{PbO}, \mathrm{BaO}$, and $\mathrm{Bi}_{2} \mathrm{O}_{3}$ in Corning D.

\section{Re-evaluation of the elemental composition of Corning archeological reference glasses}

Although the use of fs laser typically decreases laserinduced elemental fractionation, increased errors due to mass-load-induced matrix effects in the ICP can influence the quantification capabilities and figures of merit such as accuracy [50-53]. Furthermore, a detailed study about the influence of the wavelength on the accuracy needs further validation and has not been studied as extensively as for a $193 \mathrm{~nm}$ ns laser ablation system.

Therefore, the re-evaluation of the recommended values is proposed using the mean of seven LA-ICP-MS measurements at $193 \mathrm{~nm}$. These values are summarized in Table 5 with their standard deviations (SD) and compared with values from literature [2, 27, 30-32].

Table 5 New data set expressed in wt.\%

\begin{tabular}{|c|c|c|c|c|c|c|}
\hline & & Brill [2] & Brill [31] & Vicenzi [32] & $\mathrm{NEW}_{193} \pm \mathrm{SD}$ & Literature data $[27,30]$ \\
\hline \multirow[t]{4}{*}{ Corning A } & $\mathbf{P}_{2} \mathbf{O}_{5}$ & 0.13 & 0.13 & 0.13 & $0.0847 \pm 0.0007$ & $0.0341 \pm 0.0022[30]$ \\
\hline & PbO & 0.12 & 0.05 & 0.12 & $0.0725 \pm 0.0007$ & $0.0596 \pm 0.0022[30]$ \\
\hline & $\mathrm{BaO}$ & 0.56 & 0.55 & 0.56 & $0.46 \pm 0.01$ & $0.3905 \pm 0.0125[30]$ \\
\hline & $\mathrm{Cr}_{2} \mathrm{O}_{3}$ & 0.001 & 0.001 & 0.001 & $0.0033 \pm 0.0002$ & $0.0018[30]$ \\
\hline \multirow[t]{5}{*}{ Corning B } & $\mathbf{B a O}$ & 0.12 & 0.10 & 0.12 & $0.077 \pm 0.002$ & $0.08 \pm 0.02[27]$ \\
\hline & $\mathrm{SnO}_{2}$ & 0.04 & 0.03 & 0.04 & $0.0241 \pm 0.0002$ & $0.021 \pm 0.001[27]$ \\
\hline & $\mathrm{B}_{2} \mathrm{O}_{3}$ & 0.02 & 0.02 & 0.02 & $0.035 \pm 0.001$ & - \\
\hline & $\mathrm{Cr}_{2} \mathrm{O}_{3}$ & 0.005 & 0.005 & 0.005 & $0.0096 \pm 0.0003$ & - \\
\hline & $\mathrm{Bi}_{2} \mathrm{O}_{3}$ & 0.005 & 0.005 & 0.005 & $0.0042 \pm 0.0001$ & - \\
\hline \multirow[t]{5}{*}{ Corning $\mathrm{C}$} & $\mathbf{P}_{2} \mathbf{O}_{5}$ & 0.14 & 0.10 & 0.14 & $0.068 \pm 0.001$ & $0.07 \pm 0.03[27]$ \\
\hline & MnO & - & - & 0.82 & $0.0011 \pm 0.0000$ & $0.0013 \pm 0.0002[27]$ \\
\hline & $\mathrm{Sb}_{2} \mathrm{O}_{5}$ & 0.03 & - & 0.03 & $0.0001 \pm 0.0000$ & $0.0002 \pm 0.0001[27]$ \\
\hline & $\mathrm{Cr}_{2} \mathrm{O}_{3}$ & 0.001 & 0.001 & 0.001 & $0.0023 \pm 0.0001$ & - \\
\hline & $\mathrm{Bi}_{2} \mathrm{O}_{3}$ & 0.001 & 0.001 & 0.001 & $0.0040 \pm 0.0001$ & - \\
\hline \multirow[t]{3}{*}{ Corning D } & PbO & 0.48 & 0.25 & 0.48 & $0.241 \pm 0.003$ & $0.23 \pm 0.01[27]$ \\
\hline & $\mathrm{BaO}$ & 0.51 & 0.33 & 0.51 & $0.291 \pm 0.005$ & $0.38 \pm 0.09[27]$ \\
\hline & $\mathrm{Bi}_{2} \mathrm{O}_{3}$ & 0.003 & 0.002 & 0.0025 & $0.0012 \pm 0.0000$ & - \\
\hline
\end{tabular}

Bold font was used to indicate the oxides for which recommended values were given by Brill [2]; normal-font entries indicate nominal composition. The preliminary, tentative values proposed by Brill [31] are also shown here 


\section{Conclusions}

Three types of archeological reference glasses, reflecting different historical technologies of glass production, were investigated using LA-ICP-MS. The results obtained using different laser wavelengths and pulse durations (nanoseconds, 193 and $266 \mathrm{~nm}$, and femtoseconds, $800 \mathrm{~nm}$ ) were compared among each other and to recommended values from the literature. Comparison of the re-evaluated values which were proposed here with the data recommended by Brill $[2,31]$ indicated that some tentative values [31] were closer to the data set generated in this study using a 193 and an $800 \mathrm{~nm}$ laser for sampling then the values published later on [2]. The recommended quantification especially of $\mathrm{PbO}$ in Corning $\mathrm{A}, \mathrm{BaO}$ in Corning $\mathrm{B}, \mathrm{P}_{2} \mathrm{O}_{5}$ or $\mathrm{Sb}_{2} \mathrm{O}_{5}$ in Corning $\mathrm{C}$, and $\mathrm{PbO}$ or $\mathrm{BaO}$ in Corning $\mathrm{D}$ were overestimated in the final report [2], comparing to the published preliminary results [31].

Based on this LA-ICP-MS study, some significant discrepancies were found. The data indicate that the $266 \mathrm{~nm}$ laser ablation used for sampling is not suitable for quantification of these glasses using NIST 610 for calibration. Therefore, the data set generated in this study using a 193 and an $800 \mathrm{~nm}$ laser for sampling was compared with the recommended glass composition. The concentrations of $\mathrm{P}_{2} \mathrm{O}_{5}, \mathrm{PbO}, \mathrm{BaO}$, and $\mathrm{Cr}_{2} \mathrm{O}_{3}$ in Corning $\mathrm{A}$, as well as $\mathrm{BaO}, \mathrm{SnO}_{2}, \mathrm{~B}_{2} \mathrm{O}_{5}, \mathrm{Li}_{2} \mathrm{O}, \mathrm{Cr}_{2} \mathrm{O}_{3}$, and $\mathrm{BiO}_{3}$ in Corning $\mathrm{B}$ differ most significant, and some new values are proposed. This confirms reports in the literature where the determination of some trace elements, including $\mathrm{Sn}$, have been reported to be difficult (Corning B). Similar reports on $\mathrm{Cr}$, $\mathrm{Rb}$, and $\mathrm{Bi}$ in Corning $\mathrm{C}$ have been found. Therefore, corrected values for $\mathrm{MnO}, \mathrm{P}_{2} \mathrm{O}_{5}, \mathrm{Sb}_{2} \mathrm{O}_{5}, \mathrm{Cr}_{2} \mathrm{O}_{3}$, and $\mathrm{Bi}_{2} \mathrm{O}_{3}$ in Corning $\mathrm{C}$ and $\mathrm{PbO}, \mathrm{BaO}$, and $\mathrm{Bi}_{2} \mathrm{O}_{3}$ in Corning $\mathrm{D}$ are also reported. All other oxides contents in the various Corning glasses were quantified by LA-ICP-MS with good agreement to the data reported in the literature $[2,31,32]$.

Acknowledgments Financial support for the research project N N204 241734, from the Ministry of Science and High Education of Poland, is gratefully acknowledged.

Open Access This article is distributed under the terms of the Creative Commons Attribution Noncommercial License which permits any noncommercial use, distribution, and reproduction in any medium, provided the original author(s) and source are credited.

\section{References}

1. Henderson J (2000) The science and archaeology of materials. An investigation of inorganic materials. Routledge, London \& New York

2. Brill RH (1999) Chemical analyses of early glasses. The Corning Museum of Glass, vol 2. Corning, New York
3. Shortland AJ (2002) Archaeom 44:517-530

4. Dussubieux L, Gratuze B, Blet-Lemarquand M (2010) J Archaeol Sci 37:1646-1655

5. Van Der Linden V, Cosysns P, Schalm O, Cagno S, Nys K, Janssens K, Nowak A, Wagner B, Bulska E (2009) Archaeom $51: 822-844$

6. Rehren Th (2008) J Archaeo Sci 35:1345-1354

7. Mass JL (1999) The conservation of glass and ceramics. In: Tannent NH (ed) Research, practice and training. James \& James, London

8. Pollard AM, Heron C (1996) Archaeological chemistry. The Royal Society Of Chemistry, Cambridge

9. Adriaens A (2005) Spectrochim Acta Part B 60:1503-1516

10. Hogg SET, McPhail DS, Oakley VL, Rogers PS (1999) The conservation of glass and ceramics. In: Tannent $\mathrm{NH}$ (ed) Research, practice and training. James \& James, London

11. Wagner B, Nowak A, Bulska E, Kunicki-Goldfinger J, Schalm O, Janssens K (2008) Microchim Acta 162:415-424

12. De Raedt I, Janssens K, Veeckman J, Vincze L, Vekemans E, Jeffries T (2001) J Anal At Spectrom 16:1012-1017

13. Falcone R, Sommariva G, Verità M (2006) Microchim Acta 155:137-140

14. Mass J, Ammerman A, Hunt JA (2001) Amer Lab 4:52-55

15. Hall ME, Yablonsky L (1998) J Archaeol Sci 25:1239-1245

16. Arletti R, Maiorano C, Ferrari D, Vezzalini G, Quartieri S (2010) J Archaeol Sci 37:703-712

17. Kunicki-Goldfinger J, Pańczyk E, Dzierżanowski P, Waliś L (2008) J Radioanal Nucl Chem 278:307-311

18. Šmit Ž, Pelicon P, Vidmar G, Zorko B, Budnar M, Demortier G, Gratuze B, Sturm S, Necemer M, Kump P, Kos M (2000) Nucl Instrum Methods Phys Res Sect B 161-163:718-723

19. Mäder M, Jembrih-Simbürger D, Neelmeijer C, Schreiner M (2005) Nucl Instrum Methods Phys Res Sect B 239:107-113

20. Calligaro T (2008) X-Ray Spectrom 37:169-177

21. Šmit Ž, Janssens K, Bulska E, Wagner B, Kos M, Lazar I (2005) Nucl Instrum Methods Phys Res Sect B 239:94-99

22. Günther D (2002) Anal Bioanal Chem 327:31-32

23. Gratuze B, Blett-Lemarquand M, Barrandon J-N (2001) J Radioanal Nucl Chem 247:645-656

24. Giussani B, Monticelli D, Rampazzi L (2009) Anal Chim Acta 635:6-21

25. Resano M, Garcia-Ruiz E, Vanhaecke F (2010) Mass Spectrom Rev 29:55-78

26. Dussubieux L, Kusimba CM, Gogte V, Kusimba SB, Gratuje B, Oka R (2008) Archaeometry 50:797-821

27. Dussubieux L, Robertshaw P, Glascock MD (2009) Int J Mass Spectrom 284:152-161

28. van Elteren JT, Tennent NH, Selih VS (2009) Anal Chim Acta 644:1-9

29. Rbertshaw P, Benco N, Wood M, Dussubieux L, Melchiorre E, Ettahiri A (2010) Archaeometry 52:355-279

30. Shortland A, Rogers N, Eremin K (2007) J Archaeol Sci 34:781-789

31. Brill RH (1972) A chemical-analytical round-robin on four synthetic ancient glasses. The Corning Museum of Glass. Corning, New York

32. Vicenzi EP, Eggins S, Logan A, Wysoczanski R (2002) J Res Natl Inst Stand Technol 107:719-727

33. Jackson CM, Nicholson PT (2010) J Archaeol Sci 37:295-301

34. Aerts A, Velde B, Janssens K, Dijkman W (2003) Spectrochim Acta Part B 58:659-667

35. Schalm O, Caluwe D, Wouters H, Janssens K, Verhaeghe F, Pieters M (2004) Spectrochim Acta Part B 59:1647-1656

36. Kuisma-Kursula P (2000) X-Ray Spectrom 29:111-118

37. Kuisma-Kursula P, Raisanen J (1999) Archaeometry 41:71-79

38. Bronk H, Freestone IC (2001) Archaeometry 43:517-527

39. Falcone R, Renier A, Verità M (2002) Archaeometry 44:531-542

40. Mass JL, Wypyski MT, Stone RE (2002) Archaeometry 44:67-82 
41. Wolf S, Kessler CM, Stern WB, Gerber Y (2005) Archaeometry 47:361-380

42. Robertshaw P, Wood M, Melchiorre E, Popelka-Filcoff RS, Glascock MD (2010) J Archaeol Sci 37:1898-1912

43. Shortland AJ, Eremin K (2006) Archaeometry 48:581-603

44. Longerich HP, Jackson SE, Günther D (1996) J Anal At Spectrom 11:899-904

45. Jackson SE (2008) In: Sylvester P (ed) Laser ablation ICP-MS in the earth sciences: current practices and outstanding issues. Mineralogical Association of Canada, Vancouver

46. Horn I, Guillong M, Günther D (2001) Appl Surf Sci 182:91102
47. Koch J, Lindner H, von Bohlen A, Hergenroder R, Niemax K (2005) J Anal At Spectrom 20:901-906

48. Wang Z, Hattendorf B, Günther D (2006) J Am Soc Mass Spectrom 17:641-651

49. Shaheen M, Gagnon JE, Yanga Z, Fryer BJ (2008) J Anal At Spectrom 23:1610-1621

50. Kuhn H-R, Günther D (2004) J Anal At Spectrom 19:1158-1164

51. Guillong M, Horn I, Günther D (2003) J Anal At Spectrom 18:1224-1230

52. Glaus R, Kaegi R, Krumeich F, Günther D (2010) Spectrochim Acta B 65:812-822

53. Kroslakova I, Günther D (2007) J Anal At Spectrom 22:51-62 